\title{
Review of Renewable Energy-Based Charging Infrastructure for Electric Vehicles
}

\author{
Gamal Alkawsi ${ }^{1, *} \mathbb{0}$, Yahia Baashar ${ }^{1}\left(\mathbb{D}\right.$, Dallatu Abbas U ${ }^{1,2}$, Ammar Ahmed Alkahtani $^{1}\left(\mathbb{C}\right.$ and Sieh Kiong Tiong ${ }^{1}$ \\ 1 Institute of Sustainable Energy (ISE), Universiti Tenaga Nasional, Selangor 43000, Malaysia; \\ yahia.baashar@uniten.edu.my (Y.B.); abbasdallatu@gmail.com (D.A.U.); ammar@uniten.edu.my (A.A.A.); \\ Siehkiong@uniten.edu.my (S.K.T.) \\ 2 Department of Physics, Kaduna State University, Tafawa Balewa Way, Kaduna PMB 2339, Nigeria \\ * Correspondence: gamal.abdulnaser@uniten.edu.my
}

check for updates

Citation: Alkawsi, G.; Baashar, Y.; Abbas U, D.; Alkahtani, A.A.; Tiong, S.K. Review of Renewable Energy-Based Charging Infrastructure for Electric Vehicles. Appl. Sci. 2021, 11, 3847. https://doi.org/10.3390/app11093847

Academic Editor: Yosoon Choi

Received: 9 March 2021

Accepted: 15 April 2021

Published: 24 April 2021

Publisher's Note: MDPI stays neutral with regard to jurisdictional claims in published maps and institutional affiliations.

Copyright: (c) 2021 by the authors. Licensee MDPI, Basel, Switzerland. This article is an open access article distributed under the terms and conditions of the Creative Commons Attribution (CC BY) license (https:// creativecommons.org/licenses/by/ $4.0 /)$.

\begin{abstract}
With the rise in the demand for electric vehicles, the need for a reliable charging infrastructure increases to accommodate the rapid public adoption of this type of transportation. Simultaneously, local electricity grids are being under pressure and require support from naturally abundant and inexpensive alternative energy sources such as wind and solar. This is why the world has recently witnessed the emergence of renewable energy-based charging stations that have received great acclaim. In this paper, we review studies related to this type of alternative energy charging infrastructure. We provide comprehensive research covering essential aspects in this field, including resources, potentiality, planning, control, and pricing. The study also includes studying and clarifying challenges facing this type of electric charging station and proposing suitable solutions for those challenges. The paper aims to provide the reader with an overview of charging electric vehicles through renewable energy and establishing the ground for further research in this vital field.
\end{abstract}

Keywords: renewable energy; wind; solar; electric vehicle; charging station

\section{Introduction}

The remarkable increase in the use of electric vehicles (EVs) has resulted in a massive rise in demand for electric energy across the globe. The global electric vehicle market has grown significantly. The number of EVs on the road in 2010 was a few hundred; this number rose to approximately three million in 2017 and approximately six million in early 2019 [1]. Electric vehicles are exciting alternatives to conventional vehicles (CVs). With zero carbon emissions during operation, the EV has the ability to reduce total climate effect and pollutant emissions significantly. As fossil fuels are phased out to a greater degree, the need for biofuels would also be reduced. Electric motors have an efficiency of 80-95\% [2], making them a more appealing choice than CVs, which have an efficiency of less than $20 \%$ [3]. EVs are also a critical element of modern transportation, because they incorporate a variety of new industrial technologies (e.g., an electric motor, a battery, and a charging facility). However, the adoption of electric vehicles is not going as well as predicted. The limited range and slow charging time of EVs are widely regarded as the most serious barriers to promotion [4,5]. Although electric vehicles have a high purchase price, they have low maintenance costs and use substantially less energy than conventional vehicles.

According to the rapid increase of EV demand and EV charging, many research centers, and energy supplying companies began thinking seriously about reducing the pressure on local electricity networks because of the increasing number of electric vehicle charging points. Renewable energy sources such as wind and solar are some of the most effective solutions to bridge this deficit faced by local electricity networks, potentially supporting the EV charging infrastructure [6].

After the announcement of the rapid development of the EV at the turn of the millennium, renewable energy-based charging infrastructure (RCI) research began with the effort 
of wind and solar charging infrastructure [7-12]. It envisioned a charging facility that could match EV demand with renewables and direct current (DC) to improve shortcomings of conventional charging infrastructure. The traditional charging stations affect the grid's stability with issues such as harmonics, fluctuations, and voltage outages [8,9,12]. By contrast, the RCI has several advantages, such as high efficiency [13], low system cost [14], and simple arrangement $[15,16]$. Besides, it requires less power conversion levels than those in alternating current (AC)-based facilities $[17,18]$. The RCI can contribute significantly to reducing carbon emissions and expanding the energy domain's penetration of renewable energy sources. Moreover, RCI has the potential to lower the cost of EV charging [19]. However, uncertainties of the renewable sources (e.g., seasonal variations in wind speed and sun irradiance and daily randomness in cloud coverage for solar panels) and load characteristics of EVs (e.g., battery capacity, number and types of EVs, stop time, charging start time, and the initial state of charge) are serious challenges in implementing the RCI [20].

Currently, there is an ongoing considerable research work on the aforementioned topics. At the same time, other researchers are working on various aspects of implementation and operation of RCI, such as optimal planning, controlling and sizing, pricing approaches, and examination of the key factors influencing the linking of EV load directly with the RCI. For instance, few studies reviewed EV charging infrastructure research; however, they considered general technical aspects and did not concentrate on renewable energy sources (e.g., [1,21]). Another study reviewed the RCI studies but with the focus on the consumer preferences and interactions with EVs [22]. To our knowledge, no study has reviewed RCI studies extensively by discussing all related research areas.

This study examines recent advances in RCI technology and the latest research progress in this critical field. The paper discusses the concept of RCI from different perspectives, including appropriate renewable energy sources for RCI, siting, optimal planning, optimal sizing, control and energy management, and renewable energy-based charging pricing programs and challenges of RCI.

\section{Technological Infrastructure}

In many countries of the world, electric vehicles are becoming progressively more popular. However, the absence of charging stations limits the widespread acceptance of EVs by users worldwide. As EV usage grows, EV charging stations are installed in more public spaces $[23,24]$. By contrast, if the EVs are charged through an existing fossil-fuel-powered system, they will negatively affect the distribution system and the environment [25]. With solar energy from photovoltaic (PV) panels and wind sources having great potential to produce electricity, charging would be an immense solution. It would also represent a sustainable advancement towards a clean environment [23]. Depending on the sources of energy available (e.g., solar radiation and wind speed), the electricity output of the charging facility can be either inferior (less than the needed power) or very high (over the power consumption). Most of the literature indicated that the installation of PV solar systems and wind energy conversion systems with the power grid is advanced and technically viable [26].

However, the promising approach for balancing the generation of electricity from renewable energy sources can be achieved using configurable dispatch loads or energy storage systems, as it can provide electricity in low power generation [27]. The energy storage system's utilization to stabilize the power grid is no longer a new technology. Other energy sources, such as concentrated solar energy, flywheel, dedicated battery, and hydro-pumped storage systems, are some of the technologies that have been utilized. Smart meters, wireless sensors, advanced communication, and power converters are some of emerging technologies in the industry [28-32].

\subsection{Energy Storage and Fast Charging Systems}

It was reported in [33] that unregulated charging would contribute to the overloading allocation of transformers and feeders and, eventually, the power supply. Hence, most of 
the literature has suggested stationary energy storage and fast charging systems to overcome this challenging problem [33]. Energy storage limits the charging infrastructure and runs costs by serving electric vehicles during the system's uttermost load intervals $[34,35]$. Energy storage can also improve electric vehicles' stability by supplying necessary and sufficient energy to reach charging stations in the case of emergencies. Many studies were carried out on the benefits of stationary energy storage with fast charging systems $[34,36,37]$. However, to obtain such benefits, an optimum size of the energy storage system is required, taking into account the energy tariffs, expected degree of penetration, and load profiles of EVs [33].

\subsection{Storage Battery and Controller}

Solar-powered batteries can fulfill unreliable grid electricity demands, which are strong charge, discharge, and intermittent full-charging periods. A range of battery types fulfills these specific criteria. The major battery storage subgroups reviewed for solar energy include a lead-acid battery, lithium-ion battery, and flow battery [38,39].

To save the additional energy produced by photovoltaics, a central controller is required to redirect the generated power to the battery, as illustrated in Figure 1. Many scholars have investigated the sequence of controllers that are used in photovoltaics. They highlighted that it is essential to improve the productivity of solar energy generation through a maximum power point tracker (MPPT) and pulse width modulated (PWM) technologies [40].

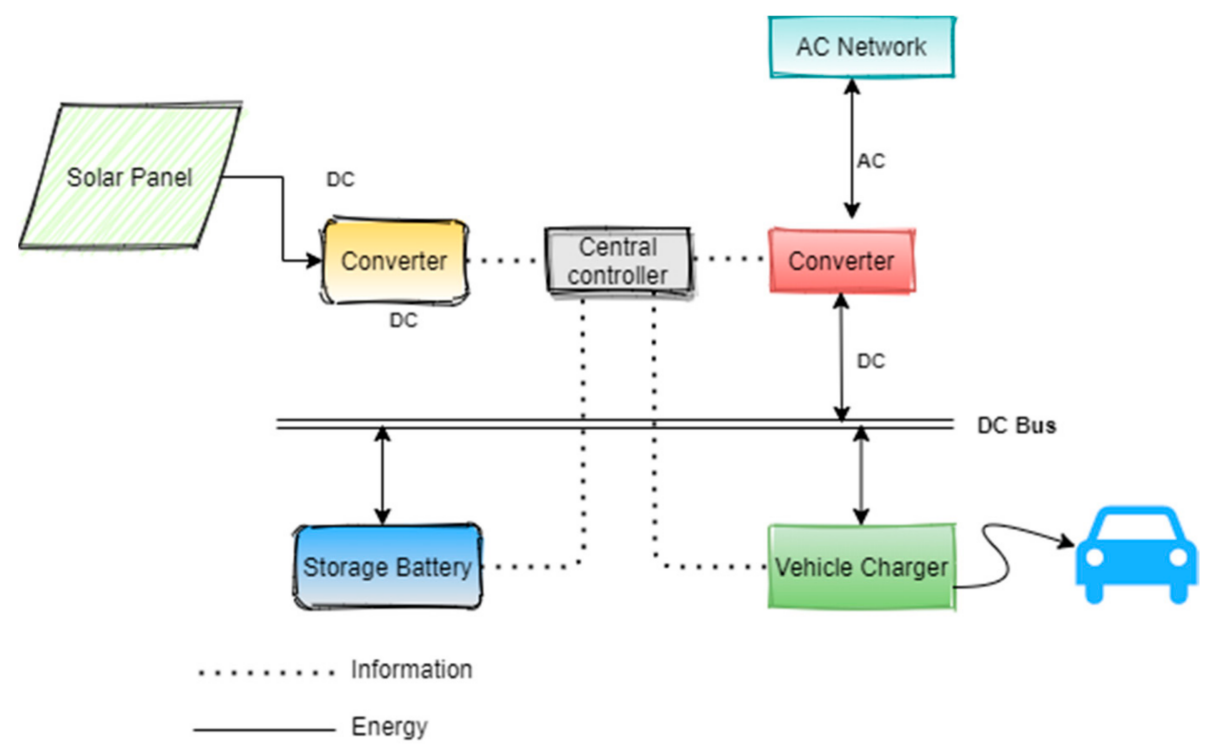

Figure 1. EV Charging Infrastructure with a Solar PV Charger.

\subsection{Converters}

When it comes to a solar converter, the PV arrays are connected to a DC/DC converter that allows for full power point tracking control. The AC/DC converter is in charge of converting $\mathrm{DC} / \mathrm{AC}$ power in a bidirectional fashion. The power used from the grid is primarily AC. It must be converted into DC to charge the electric vehicles. The conversion of power occurs before the charging begins or relays the power from the grid to electricity networks.

Therefore, the converters have unique roles in photovoltaic systems based on balanced energy conversion [41]. Different forms and requirements have been examined in detail, for example, string inverters, in which panels are installed in combination with a microinverter, and central inverters, where panels are installed with separate inverters and micro-inverter power optimizers that require further monitoring. These power optimizers are used to track photovoltaic panel arrays' overall performance to constantly alter and change the attached load that keeps the system at maximum operational capability [42]. 


\section{Appropriate Renewable Energy Sources}

Wind and solar energies are considered to be reliable substitution sources of conventional energy sources because of their economic and environmental benefits [11,43-45]. However, one of the disadvantages of these renewable sources is their inconsistency in offering energy. They do not generate power all the time, and they are intermittent. However, a few suggestions for solar-based charging facilities are discussed in $[35,36,46]$. The researchers proposed charging infrastructure dedicated to the range of low to medium EVs. In [47], the researchers suggested charging EVs from solar energy using the DC link voltage sensing. The aim is to lower the burden on the distribution transformer. However, solar energy limitation to charge wide-range EVs will lower the chances of implementing more solar-based charging stations.

Research work on the control and optimization of wind turbines (WT) has demonstrated that wind energy is an appropriate choice for EV charging infrastructure. In [44], the researchers discussed the advantages of implementing charging stations based on large-scale turbines and found that EVs could be a critical factor for enabling the high penetration of wind energy. Considering the challenges of traditional scheduling and dispatching mechanisms, researchers in [48] developed a model of utilizing the flexibility of charging EVs to optimally compensate for wind energy fluctuations. They found that shifting EVs' charging to times with high wind availability achieved cost savings. In another study [49], the possibility of using wind energy as a direct source for power EV charging stations were investigated. The researchers implemented an interval-based method corresponding to the time slot taken for EV charging for wind energy conversion and evaluated using various constraints and parameters, including the averaging time interval for wind speed, different turbine manufacturers, and regular high-resolution wind speed datasets. The analysis indicated that the use of direct wind to EV provides enough constant power for large-scale charging stations.

The researchers in [50] developed optimal charging infrastructure using wind turbines for different charging modes concerning the optimal charging power. The infrastructure is connected to the grid and has an energy storage system. The rated power was optimized on 52,84 , and $116 \mathrm{~kW}$ for slow, intermediate, and quick-speed charging, respectively. On the other hand, the study [50] developed a power management model to enhance wind energy reliability.

However, we can conclude that solar and wind energies are appropriate sources for EV charging infrastructure. A charging facility can be either hybrid (solar and wind) or non-hybrid with the use of suitable storage capacity to support the charging process during the fluctuation of sources. The power generator's sizing depends mainly on the type of charging (fast, medium, or slow). Nonetheless, the use of battery storage has a negative impact on the environment. The study results of [51] indicate that global electronic mobility demand will boost the production of batteries by 2030 to around $1725 \mathrm{GWh}$, and nickel will be the dominant raw material in the lithium-ion battery. Currently, batteries' demand represents $4 \%$ of the annual global nickel production, and the gradual scenario is that nickel demand would rise to $34 \%$ of present mining production in 2030. Even if nickel is an important component for plants, like every metal and chemical, the quality of the environment for flora and fauna may be negatively affected by its excessive amounts. As a result, nickel is strictly controlled and subjected to rigorous evaluations under a variety of legislative frameworks [52].

\section{Siting}

\subsection{Home Charging}

Home charging involves private and public charging points in residential areas. Few survey studies have found that the EV's drivers consider home charging as a motivational factor for buying EV where it is easy to access $[22,53,54]$. The implementation of more home charging (HC) infrastructure could increase EVs' adoption rate, especially in cities $[55,56]$. The HC infrastructure is dominant over the other kinds of infrastructure. The report on 
energy efficiency and renewable energy in the USA indicates that approximately $80 \%$ of the installed charging infrastructure is for $\mathrm{HC}$, and most of the charging sessions for EVs happened in residential areas $[57,58]$. This indicates the reliance on EVs' on-grid electricity, where most charging takes place in residential areas. Deploying more solar-based charging infrastructure in residential areas could, therefore, lower reliance on the grid, encourage EV adoption rate, and extend the use of clean energy sources. As a result, that could lower greenhouse gas emissions and air pollution.

\subsection{Workplace Charging}

Companies are starting to implement an electric infrastructure for their employees, or workplace charging (WC), to demonstrate their commitment to the green environment concept. Because of the extended parking period, the workplace is considered as the second location for employees with a higher opportunity to charge EVs outside homes, where $15-25 \%$ of charging events occur at the workplace [22]. Few companies provide renewable energy charging in the workplace, offering to charge at a shallow or sometimes free rate (e.g., Google and DirectTV). Provision of the WC infrastructure can increase the daily driving distance that leads to raising EVs' adoption rate and usability. On the other hand, the parked vehicles can be considered to be a distributed resource that can provide electricity to the grid, known as the vehicle to grid (V2G). This integration can make efficient utilization of renewable energy. Meanwhile, renewable energy can be connected to the grid or to a microgrid nearby to solve renewable energy sources' fluctuations.

\subsection{Public Charging}

The public charging (PC) infrastructure is charging stations that EVs' drivers can easily access when needed. They are more suitable for implementing renewables' facilities than residential areas. Deployment of renewables' facilities in residential areas has several problems such as parking availability, building limitations (e.g., not enough space for solar panels), and governance issues (e.g., wind farms are, as a rule, sparse out of cities) [59]. The public charging stations include the following:

\subsubsection{Opportunity Charging Stations}

Opportunity charging stations (OCSs) present EV drivers' opportunity to recharge during the parking time at public locations. They are locations like shopping malls, airports, supermarkets, schools, parks, and restaurants. Drivers are expected to park for half an hour and more [60]. The network charging agreement can incorporate OCS to set an encouraging cost model, where EVs drivers can pay a fixed amount monthly as a subscription, pay-asyou-go plans, or, in some scenarios, for free.

\subsubsection{Fast Charging Stations}

Fast charging stations (FCSs) can solve the charging time issue, which is a crucial element in adopting and deploying EVs. The fast charging works on recharging the EVs quickly, similarly to the conventional vehicles at gasoline stations. Fast-charging plays a vital role in increasing EVs' traveling distance by having FCS along the way. The off-board fast charging module is the key to fast-charging stations whose output is $35 \mathrm{~kW}$ and higher. The corresponding current and voltage ratings are 20-200 A and 45-450 V, respectively. As they are both so high, such infrastructures have to be deployed in supervised centers or stations.

\subsubsection{Battery Exchange Station}

A battery exchange station (BES) is a system that EV drivers can replace their discharged battery with a fully charged battery at BES. The implementation of BES can provide several benefits, such as its very fast exchanging time. For example, Tesla, a well-known electric vehicle maker, swap EV batteries in $90 \mathrm{~s}$ [61]. One more critical issue about BES benefits is avoiding charging during peak demand [62]. Other benefits of BES are min- 
imal cost management, long battery lives, and low consumption [63]. However, there are few drawbacks of the BES, such as the cost of investment, which is very high. BES construction requires ample space, and the battery management system cannot ensure battery safety [64].

\section{Optimal Planning}

The EVs' charging requirement is complicated; therefore, it is not easy to accurately estimate or precisely obtain it. As presented in Table 1, the literature consists of research papers related to the charging scheduling issue. Some of these studies describe the integration of renewable sources with V2G technology during the charging station's planning [65-69]. The other set of these research papers are focused on the BES [70,71].

Charging station planning is a challenging task. It includes considering the availability of renewable sources, uncertainties in traffic demands, the complex nature of location design, and other factors affecting hourly power management such as renewable source, grid peak hours, and V2G. Thus, in a charging station, there is a need to link long-term planning decisions (e.g., location, size, and operation hours) with short-term operation decisions (e.g., grid power usage, the number of batteries charged/discharged, energy storage, V2G, and renewables) to form a planning framework. Besides, the availability of the data allows designers of fast-charging stations to have access to the EVs' data over transportation networks, including historical data and real-time charging demand. The collected data encourage an innovative data-driven pattern. Table 2 describes some studies that applied a data-driven approach.

Moreover, in the built environment applications, the energy system planning models should have data standardization, interpretability, scalability, flexibility/adaptability, and reconfigurability [72]. These features can serve as the foundation for future modeling research to develop and deploy models in IoT-based systems as digital twins of real-time processes. Digital twins will be developed in a hierarchical and interconnected fashion, rather than being designed for individual and separate applications.

Table 1. Charging station planning.

\begin{tabular}{|c|c|c|c|}
\hline Study & Modeling Technique & Source & Station Type \\
\hline [73] & \multirow{2}{*}{$\begin{array}{l}\text { Stochastic programming } \\
\text { Mixed-integer linear } \\
\text { programming (MILP) }\end{array}$} & \multirow{2}{*}{$\begin{array}{l}\text { Grid, Solar } \\
\text { Grid, Wind, vehicle to } \\
\text { grid (V2G) }\end{array}$} & Charging Station \\
\hline [67] & & & Charging Station \\
\hline [70] & Two-stage stochastic MILP & Grid, Solar & $\begin{array}{l}\text { Battery Exchange Station } \\
\text { \& Charging Station }\end{array}$ \\
\hline [65] & Two-stage stochastic MILP & Grid, wind, V2G & Charging Station \\
\hline [68] & Stochastic Optimization & Grid, Wind & Charging Station \\
\hline [69] & Probabilistic Model & Grid, Wind, Solar & Charging Station \\
\hline [71] & Two-stage stochastic MILP & Grid, Solar & Battery Exchange Station \\
\hline [66] & MILP & Grid, Wind & Charging Station \\
\hline
\end{tabular}

Concerning the design of RCI, it was noticed that its reliability and cost are the standards considered the most in the charging stations. However, environmental objectives and social factors should be given more attention, mainly when the charging station includes a conventional source. The social factors influence optimal planning methods as they are affected by energy savings and the total cost of integrating renewables sources. Thus, consideration of such factors in optimal planning methods is recommended. 
Table 2. Data-driven models.

\begin{tabular}{|c|c|c|c|}
\hline Study & Modeling Technique & Problem to Solve & Findings \\
\hline$[74]$ & Power requirement model & The behavior of the power grid & $\begin{array}{l}\text { Lacks the electrical behavior } \\
\text { information of the network while } \\
\text { charging, so these models have their } \\
\text { importance if connected to an } \\
\text { electrical network }\end{array}$ \\
\hline [75] & Queueing model & $\begin{array}{l}\text { The probability distribution of } \\
\text { getting charged EVs }\end{array}$ & $\begin{array}{l}\text { The EVs can determine the siting of } \\
\text { charging stations by providing } \\
\text { waiting spots; in addition to charging } \\
\text { spots, the utilization of chargers } \\
\text { increases, and the number of required } \\
\text { chargers at each site decreases }\end{array}$ \\
\hline [76] & $\begin{array}{c}\text { The distributional robust travel } \\
\text { time information gain sensor } \\
\text { location } \\
\text { (DRTTIGSL) model }\end{array}$ & $\begin{array}{l}\text { Uncertainty in the prior travel } \\
\text { time distribution }\end{array}$ & $\begin{array}{l}\text { The model can reduce the worst-case } \\
\text { situation with a small price of the } \\
\text { average objective value, especially } \\
\text { when the total budget is not high }\end{array}$ \\
\hline [77] & $\begin{array}{l}\text { The data-driven constraints are } \\
\text { reformulated into tractable } \\
\text { counterparts by the sample } \\
\text { average approximation } \\
\text { (SAA) approach. }\end{array}$ & $\begin{array}{l}\text { Siting and sizing standalone } \\
\text { electric-vehicle charging stations }\end{array}$ & $\begin{array}{l}\text { The SAA approach merely } \\
\text { investigates the empirical probability } \\
\text { distribution and ignores the true one }\end{array}$ \\
\hline
\end{tabular}

\section{Optimal Sizing}

In recent years, the transportation sector has witnessed a rapid penetration of electric vehicles (EVs). The aim is to enable the sustainability of the system. It was driven by modern innovations in battery technology and in the electric drivetrain. However, as electric vehicles' penetration spreads, the EVs' demand increases, thus introducing additional load to the power systems. There is a need to upgrade and increase the capacities of the electricity distribution systems to contain the overloading challenge and integrate renewable energy sources (RESs) into the charging station. In addition, meeting the ever-increasing $\mathrm{EV}$ demands through optimum sizing and operation of the EV charging stations is the most challenging task. Several studies have been reported with regard to addressing the aforementioned challenges and are presented as follows.

In [78], an EV charging station was designed with solar-wind hybrid power sources. The Hybrid Optimization Model for Electric Renewables (HOMER) software was employed for sizing the renewable energy source and for power-sharing to the loads. With one $200 \mathrm{~kW}$ capacity WT unit and PV panels, a total power of $250 \mathrm{~kW}$, a total annual energy generation of $843,150 \mathrm{kWh}$ was realized. The charging station has the capacity of charging $5 \mathrm{EVs}$ in $1 \mathrm{~h}$. Likewise, in [79], the MATLAB environment was used to develop a mathematical model of optimal sizing and capacity allocation using the differential evolution (DE) algorithm for a wind energy system that is integrated with an EV battery exchange station.

A $200 \mathrm{~kW}$ wind generator and $10 \mathrm{~kW}$ charge and discharge machine were used to provide energy to both EVs for traveling demand and the entire system's energy balance. The analysis based on the condition of the components regarding power change at different periods reveals that the optimum solution is logical, and through the hybrid system concept, the EVs' energy demand can be achieved. In the same vein, a multi-objective optimization problem based on the DE algorithm was developed by [80] to obtain optimal sizing of EV charging stations and renewable energy sources. The performance of the proposed method is evaluated in MATLAB for different microgrids. The simulation results provided the optimal size of charging stations for the number of EVs based on the optimal load factor, power loss, and voltage profile. Similarly, a hybrid improved optimization algorithm based on Genetic Algorithm-Particle Swarm Optimization (GA-PSO) was used by [81] for the optimal sizing of renewable energy sources (RES) and EVs' charging demand. 
In a slightly different perspective, [82] presented the optimal design and comparative studies for an isolated EV charging station (EVCS) and a grid-connected EVCS as a smart energy hub configuration. This study's various supply options are diesel-based, solar PV with battery energy storage system (BESS)-based, and diesel-solar PV-BESS mix. The studies were carried out using HOMER software, which considered different dispatch strategies that yield the minimum project cost for each EVCS configuration.

To adequately cater to the increased demand for EV charging resulting from the ever-rising EVs users, it becomes inevitable to provide fast and easily accessible charging infrastructures. Concerning the fast-charging concept, Santiago et al. [83] analyzed the technical and economic viability of an off-grid photovoltaic-battery energy storage system (PV-BESS) for fast-charging EVs. The whole system's optimum sizing was performed with HOMER software using the meteorological data and then enhanced the result using the principle of load shifting. With $281.52 \mathrm{~kW}$ PV modules, a total of $12 \mathrm{EVs}^{\prime}$ complete recharges of $35 \mathrm{k}$ Wh for the period of $13.5 \mathrm{~h}$ per day were achieved using a $50 \mathrm{~kW}$ DC fastcharging device. Similarly, [84] proposed a strategy for BESS's sizing within a fast-charging station (FCS). The charging station's load has been estimated by the stochastic load profile of individual EVs registered with the FCS. The mathematical model result revealed that the FCS demand depends on the FCS charging level, the number of EVs in the FCS, the residual energy level of EVs, and the battery size of EVs registered with the FCS. Likewise, [85] developed a probabilistic planning model for optimal sizing and allocation of EVs' fastcharging stations. The load level of the EVs' charging demand was modeled based on queuing theory $(\mathrm{QT})$. The exponential distribution function was employed to determine each charging device's service time while the EVs' charging demand was estimated using the poisoning process.

\section{Control and Energy Management}

Connecting the renewable energy-based stations to the grid leads to several challenges. Besides the grid integration and fluctuation issues, the charging operation presents a critical shortage due to the inharmonious charging process concerning power quality and demand [86], specifically for fast-charging stations [87]. Hence, it is crucial to control the charging behavior to reduce these issues' impacts. For example, an analysis of electricity production conducted by [88] to calculate relevant performance indicators of the electricity supplied by the grid indicated significant variability of the $\mathrm{CO}_{2}$ emissions. It highlights the need for accurate knowledge of operational parameters to support future smart grid management. Therefore, the management of the EV charging behavior would moderate the fluctuation of renewable energy, optimize the grid's peak demand, and make efficient load characteristics of the grid [89]. The literature comprises several studies on impacts of charging loads on the grid. For example, Green et al. [90] studied impacts of EVs on the distribution network, and Amini et al. [91] discussed effects of large-scale charging infrastructure on the system's total loss. In [92], a probabilistic model is used to investigate incremental impacts of EV charging on the distribution network.

Management of the charging process in a controlled mode increases the capacity of charging a large number of EVs. Using the maximum renewable energy generated and smart coordination with the grid can decrease the power load of the charging equipment on the grid and ensure cleaner energy. By contrast, integrating the energy storage with the charging station enables disengaging EV load from the grid, moving the charging time to off-peak, and controlling renewable energy's uncertainty and fluctuation [87].

Moreover, most EVs' parking time is up to $95 \%$ per day in the charging area; thus, the V2G concept was raised [93]. EVs can be charged at low pricing hours and discharge at high pricing hours, making EVs a distributed energy facility. This mechanism offers EV drivers the chance to lower the charging cost through the price difference [94]. The excellent interaction among the grid and large-scale or high-distance range EVs leads to the smart charging and discharging strategy [95]. 
The literature has many studies concerning energy management for EVs associated with renewable energy sources. For example, Wi et al. [96] proposed a charging control algorithm to schedule EV charging associated with PV in smart buildings. The proposed strategy is based on predicted PV energy generation and baseload power demand. However, uncertainties of EV charging demand were not considered. Similarly, another scheduling algorithm was proposed by [97] for smart buildings that can efficiently reduce $\mathrm{CO}_{2}$ emissions. However, the study did not consider the flexibility of EV charging demand.

Several studies consider appropriate strategies for controlling EV charging. For instance, Razo et al. [98] proposed a vehicle-originating-signals strategy for controlling EV charging by reducing communication overhead with minor effects on performance. Liao et al. [99] proposed a scheme for EV charging control that considers the energy storage system and renewable energy power. In [100], an optimal scheduling method was introduced for charging infrastructure associated with a microgrid. Kumar et al. [101] evaluated various combinations of different priority control criteria on EVs' ability to charge and charging fairness. Table 3 summarizes the other recent studies concerning energy management of renewable energy-based charging infrastructure. It is noticeable that the dominant criterion is focused mainly on the energy management associated with a PV system that is connected to the grid; consequently, the wind energy and the energy storage system are not sufficiently considered.

Table 3. Energy management studies related to renewable energy-based charging stations.

\begin{tabular}{|c|c|c|c|c|}
\hline Study & Configuration & Aim & Method & Remarks \\
\hline [102] & $\begin{array}{l}\text { Standalone hybrid } \\
\text { renewable systems }\end{array}$ & $\begin{array}{l}\text { Minimizing the use of battery } \\
\text { storage and maximizing the } \\
\text { use of renewable sources with } \\
\text { zero charging rejection }\end{array}$ & $\begin{array}{l}\text { The simulation was } \\
\text { developed to find the } \\
\text { minimum of a } \\
\text { constrained non-linear } \\
\text { multi-variable function }\end{array}$ & $\begin{array}{l}\text { Different scenarios are } \\
\text { introduced and analyzed }\end{array}$ \\
\hline [103] & $\begin{array}{l}\text { Standalone hybrid } \\
\text { renewable systems }\end{array}$ & $\begin{array}{l}\text { Optimal scheduling for } \\
\text { power supply }\end{array}$ & $\begin{array}{l}\text { The energy resources and } \\
\text { realistic EV charging data } \\
\text { were simulated }\end{array}$ & $\begin{array}{l}\text { The power scheduling } \\
\text { was optimized }\end{array}$ \\
\hline [104] & PV-WT-Grid & $\begin{array}{l}\text { Maximizing use of } \\
\text { renewable sources }\end{array}$ & $\begin{array}{l}\text { Experimenting with the } \\
\text { maximum power point } \\
\text { tracking technique }\end{array}$ & $\begin{array}{l}\text { The infrastructure is } \\
\text { capable of providing } \\
\text { sufficient energy in } \\
\text { response to the } \\
\text { load demand }\end{array}$ \\
\hline [105] & PV-BESS-Grid & $\begin{array}{l}\text { Support of high charging rates } \\
\text { and penetration of the energy } \\
\text { system into the grid }\end{array}$ & $\begin{array}{l}\text { Simulation and } \\
\text { prototype experimental }\end{array}$ & $\begin{array}{c}\text { They demonstrated the } \\
\text { effectiveness and benefits } \\
\text { of a hybrid grid-connected } \\
\text { energy system }\end{array}$ \\
\hline [106] & PV-Grid & $\begin{array}{l}\text { Discussing critical aspects of } \\
\text { renewable resources-based } \\
\text { fast charging }\end{array}$ & Review & $\begin{array}{c}\text { Recommendations and } \\
\text { useful information related } \\
\text { to renewable energy-based } \\
\text { DC fast charging }\end{array}$ \\
\hline [107] & $\begin{array}{c}\text { WT-Diesel } \\
\text { Generator-BESS }\end{array}$ & $\begin{array}{l}\text { Minimizing use of the dump } \\
\text { load normally associated with } \\
\text { diesel operation }\end{array}$ & Simulation & $\begin{array}{l}\text { Optimizes } \\
\text { charging/discharging } \\
\text { cycles of the storage system } \\
\text { and system operation cost }\end{array}$ \\
\hline
\end{tabular}


Table 3. Cont.

\begin{tabular}{|c|c|c|c|c|}
\hline Study & Configuration & Aim & Method & Remarks \\
\hline [108] & PV-Grid & $\begin{array}{c}\text { Improving } \\
\text { self-consumption of PV } \\
\text { energy and lower its } \\
\text { impacts on the grid }\end{array}$ & $\begin{array}{l}\text { Simulation-based on } \\
\text { real-time data acquisition } \\
\text { of the demand and } \\
\text { generation } \\
\text { without forecasting }\end{array}$ & $\begin{array}{l}\text { Proves the proposed } \\
\text { strategy's efficiency that } \\
\text { can be used in embedded } \\
\text { systems for real-time } \\
\text { allocation of the EV } \\
\text { charging rate }\end{array}$ \\
\hline [19] & PV-Grid & $\begin{array}{l}\text { Comparing an optimal } \\
\text { charge-scheduling strategy } \\
\text { with an uncontrolled } \\
\text { charging case }\end{array}$ & $\begin{array}{l}\text { An hourly simulation was } \\
\text { used by considering } \\
\text { statistical data for driving } \\
\text { distances, different types of } \\
\text { vehicles, parking time, } \\
\text { installation cost, tax rebates } \\
\text { and incentives }\end{array}$ & $\begin{array}{l}\text { Confirms feasibility } \\
\text { of PV-based infrastructure, } \\
\text { benefits to EVs' drivers and } \\
\text { the garage owner and the } \\
\text { need for an optimal } \\
\text { charging controller }\end{array}$ \\
\hline [96] & PV-Grid & $\begin{array}{l}\text { Determining optimal } \\
\text { schedules of EV according } \\
\text { to the predicted PV power } \\
\text { and demand }\end{array}$ & Simulation and prototype & $\begin{array}{l}\text { Demonstrates the } \\
\text { effectiveness of the } \\
\text { proposed smart EV } \\
\text { charging method }\end{array}$ \\
\hline [109] & PV-Grid & Minimizing operation costs & $\begin{array}{l}\text { Simulation and } \\
\text { economic analysis }\end{array}$ & $\begin{array}{l}\text { Confirms applicability of } \\
\text { the strategy to DC } \\
\text { distribution buildings, for } \\
\text { energy cost reduction }\end{array}$ \\
\hline [110] & PV-Grid & $\begin{array}{l}\text { Providing a day-ahead } \\
\text { upper limit profile of the } \\
\text { charging infrastructure's } \\
\text { power consumption }\end{array}$ & $\begin{array}{l}\text { Simulations and } \\
\text { sensitivity analysis }\end{array}$ & $\begin{array}{c}\text { Demonstrates feasibility } \\
\text { and relevance of the } \\
\text { proposed strategy }\end{array}$ \\
\hline [111] & $\begin{array}{l}\text { PV-WT-Fuel } \\
\text { Cells-Grid }\end{array}$ & Minimizing the total cost & $\begin{array}{l}\text { Simulations based on the } \\
\text { genetic algorithm method }\end{array}$ & $\begin{array}{c}\text { Presents the optimal } \\
\text { number of parking lots } \\
\text { under optimal scheduling } \\
\text { of PHEVs }\end{array}$ \\
\hline [112] & $\begin{array}{l}\text { PV-WT- Thermal } \\
\text { Storage-BESS-Grid }\end{array}$ & $\begin{array}{l}\text { Minimizing operating costs } \\
\text { and } \mathrm{CO}_{2} \text { emissions }\end{array}$ & Case study & $\begin{array}{l}\text { Demonstrates reduction in } \\
\text { costs and } \mathrm{CO}_{2} \text { emissions }\end{array}$ \\
\hline [113] & $\begin{array}{c}\text { PV-WT- Fuel Cells } \\
\text {-Grid }\end{array}$ & $\begin{array}{l}\text { Integrating scheduling and } \\
\text { management of } \\
\text { intermittent renewable } \\
\text { generation and EVs in } \\
\text { a microgrid }\end{array}$ & Case study & $\begin{array}{l}\text { Satisfies technical and } \\
\text { financial objectives of } \\
\text { infrastructure and } \\
\text { economic and security } \\
\text { issues of the microgrid }\end{array}$ \\
\hline [114] & PV-BESS-Grid & Reducing operation cost & $\begin{array}{l}\text { Simulation based on two } \\
\text { algorithms and a } \\
\text { case study }\end{array}$ & $\begin{array}{l}\text { The case study confirms } \\
\text { effectiveness of the } \\
\text { proposed algorithms in } \\
\text { reducing the cost }\end{array}$ \\
\hline
\end{tabular}

\section{Pricing Programs}

To date, there is a small number of utility programs that provide EV charging based on renewable sources. Even though a limited number of programs have offered EVs' renewable charging, the existing programs in Austin (USA) [115] and Saint Paul (France) [116] indicate that the third EV drivers choose renewable energy. An annual billing of renewable energy can be used for EV electricity demand. However, programs that use the charging times can request suitable and renewable energy supplies, thus providing significant advantages to customers and utilities. Customers can charge at a beneficial rate, and utilities can manage system peaks [117].

Giant utilities can provide network solutions for charging electric vehicles with renewable sources for retail, employee, and commercial customers. The network solutions are outcomes of promising programs that make EV drivers depend more on renewable sources [115]. Another program works on encouraging EV drivers to charge during preferred times of the day by offering financial incentives, for instance, linking the charging times with renewables' availability $[118,119]$. Renewables' pricing and time of charge are 
factors influencing participant interest. In other programs, the green pricing has been paired with time of use (TOU) rates to attract small commercial and residential customers to charge EVs with renewables; this leads to cost savings of charging at periods of excess renewable generation or during off-peak periods [117]. A comparison of the existing charging programs is depicted in Table 4.

Table 4. Renewables' charging programs.

\begin{tabular}{|c|c|c|c|c|}
\hline Approach & Advantages & Programs/Plans & Example of Costing & Utility \\
\hline $\begin{array}{c}\text { Renewables' network } \\
\text { charging }\end{array}$ & $\begin{array}{l}\text {-Enables customers to charge } \\
\text { with renewable sources. } \\
\text {-Encourages drivers to } \\
\text { charge at beneficial times }\end{array}$ & $\begin{array}{l}\text {-Pay per use. } \\
\text {-Monthly flat fee }\end{array}$ & $\begin{array}{l}2 \text { USD per } h \\
4.17 \text { USD per month }\end{array}$ & Austin Energy \\
\hline $\begin{array}{l}\text { Offers for time-shifting } \\
\text { and renewables' access. }\end{array}$ & $\begin{array}{l}\text {-Encourages charging at } \\
\text { more suitable times for the } \\
\text { grid by considering the } \\
\text { availability of renewables } \\
\text { and avoiding peak hours }\end{array}$ & $\begin{array}{l}\text {-Charging with } \\
\text { renewable energy. } \\
\text {-Merge TOU rates with } \\
\text { renewables' } \\
\text { pricing program }\end{array}$ & $\begin{array}{l}\text { No extra cost for wind } \\
\text { energy or } \\
0.02 \text { USD per kWh }\end{array}$ & $\begin{array}{l}\text { Great River } \\
\text { Energy \& } \\
\text { Potomac Electric } \\
\text { Power Co. }\end{array}$ \\
\hline $\begin{array}{l}\text { Pair on-site renewables' } \\
\text { charging with EV } \\
\text { charging }\end{array}$ & $\begin{array}{l}\text {-Free management and } \\
\text { control charging }\end{array}$ & $\begin{array}{l}\text {-Beneficial } \\
\text { charging rate } \\
\text {-Free employee } \\
\text { charging }\end{array}$ & Cost varied & $\begin{array}{l}\text { San Diego's Solar } \\
\text { and Google LLC }\end{array}$ \\
\hline Smart charging & $\begin{array}{l}\text {-Allows utilities to control } \\
\text { charging remotely to meet } \\
\text { grid needs. }\end{array}$ & $\begin{array}{l}\text {-Managed } \\
\text { charging program }\end{array}$ & Cost varied & $\begin{array}{l}\text { Pacific Gas \& } \\
\text { Electric/BMW }\end{array}$ \\
\hline $\begin{array}{l}\text { Matching rate with } \\
\text { surplus } \\
\text { renewable energy }\end{array}$ & $\begin{array}{l}\text {-Shifts charging loads to } \\
\text { times when there is excess } \\
\text { renewable energy generation } \\
\text { on the grid }\end{array}$ & $\begin{array}{l}\text {-Time of use } \\
\text { (TOU) rates }\end{array}$ & $\begin{array}{l}\text { Varies from } 0.9 \text { to } 1.5 \\
\text { USD per } \mathrm{kWh}\end{array}$ & Xcel Energy \\
\hline
\end{tabular}

\section{Challenges of Renewable Energy-Based Charging Infrastructure}

Power quality: It was noticed that generating renewable power could introduce power quality problems. According to the changing nature of wind and solar, generating renewable power is intermittent, with high fluctuations, and non-dispatchable [120]. The RCI features mainly in charge of power quality challenges include the modularity of renewable generators. Power quality seems to be one of the most critical aspects that could affect the reliability and stability of RCI.

Stability: It refers to the recovery of the power system after blackouts and control of the voltage and frequency. Stability challenges are mostly caused by the excess of power from renewable energy, and battery storage that can cause significant damage to RCI [121]. Controlling the stability can ensure the power system is performing correctly and not approaching instability.

Power balance: The power unbalancing occurs in RCI because of the renewable sources' uncertainty and variability. This challenge relates to the long-term balance of active supply and load in the power system. This includes the system-wide coordination of ramp rate capacities and minimum generation levels of a power system [122].

Charging prices: The vast implementation of renewables alters the structure of costing to be capital intensive. To ensure that implementation is profitable, the pertinent planning firms need to consider long-term energy prices [123]. Notably, the number of utility programs that offer renewable energy-based EV charging is limited and only concerned about residential customers. There is a need for various approaches to serve heavy-duty vehicles, employee workplace charging, and retail customers at the public charging loads.

Locations: The literature demonstrates several attempts to evaluate medium- and large-scale wind farms to secure energy demand required by the EV charging infrastructure. It was noticed that urban areas are not suitable for installing the turbines as the wind energybased system requires broad premises. The large buildings are the major obstacles in wind 
directions. However, some city authorities do not allow heavy-duty vehicles to enter cities at specific times. Thus, installing charging infrastructure in suburban or rural areas can serve medium- and heavy-duty vehicles.

By contrast, the installation of RCI in urban areas could face some problems. For instance, in multi-unit residential buildings, the study [59] stated several problems: parking availability, building limitations, and governance issues. Hence, optimal planning of location and optimal scheduling for charging are critical factors that must be considered in implementing RCIs.

\section{Conclusions}

The integration of renewable energy and EVs draws the future mode of transportation. The more penetration of EVs and RCIs means more reduction of carbon emissions and fossil fuel consumption. However, there are some challenges for the deployment of renewable energy-based infrastructures due to their natural fluctuation. For wind turbines, the location and environmental factors are critical issues for installation. Urban areas have been found to be unsuitable because of their noise and requirement for spacious premises. For solar systems, the focus of electricity production is only on the daytime; this limits its supply in meeting the significant typical electricity demand.

Wind and solar energy are considered to be good sources for EV charging infrastructure. However, their integration with EVs, V2G charging facilities, and ESS can form RCI with a microgrid plan for network charging. In optimal planning, it was noticed that active research concerns the charging scheduling issue. Some of them consider the integration of renewable sources with V2G during the planning phase. RCI planning is challenging because of the availability of renewable sources, uncertainties in traffic demands, the complex nature of location design, and other factors affecting the hourly power management such as renewable source, grid peak hours, and V2G. The literature demonstrates the lack of studies in renewables' charging infrastructure in adopting real data to improve control strategies, sizing, and real-time control. In control and management, the excellent interaction among the infrastructure and high-distance range EVs leads to the smart charging and discharging strategy. Charging pricing approaches indicate a limited number of utility programs that support renewable charging, and they are only focused on residential customers. New charging programs must be introduced for heavy-duty vehicles and retail customers at public charging loads.

Author Contributions: Conceptualization, G.A. and A.A.A.; methodology and investigation, G.A.; resources, G.A., Y.B., and D.A.U.; writing—original draft preparation, G.A., Y.B. and D.A.U.; writingreview and editing, G.A., A.A.A., and S.K.T.; supervision, A.A.A.; project administration, S.K.T.; funding acquisition, A.A.A. and S.K.T. All authors have read and agreed to the published version of the manuscript.

Funding: This research was funded by Universiti Tenaga Nasional under the BOLDREFRESH2025 Fund.

Institutional Review Board Statement: Not applicable.

Informed Consent Statement: Not applicable.

Data Availability Statement: Not applicable.

Acknowledgments: Authors acknowledge the publication support through J510050002 -BOLDREFRESH2025-CENTRE OF EXCELLENCE from the iRMC of Universiti Tenaga Nasional.

Conflicts of Interest: The authors declare that there is no conflict of interests. The funders had no role in the design of the study; in the collection, analyses, or interpretation of data; in the writing of the manuscript; or in the decision to publish the results.

\section{References}

1. Das, H.S.; Rahman, M.M.; Li, S.; Tan, C.W. Electric vehicles standards, charging infrastructure, and impact on grid integration: A technological review. Renew. Sustain. Energy Rev. 2020, 120, 109618. [CrossRef] 
2. Canals Casals, L.; Martinez-Laserna, E.; Amante García, B.; Nieto, N. Sustainability analysis of the electric vehicle use in Europe for $\mathrm{CO}_{2}$ emissions reduction. J. Clean. Prod. 2016, 127, 425-437. [CrossRef]

3. Åhman, M. Primary energy efficiency of alternative powertrains in vehicles. Energy 2001, 26, 973-989. [CrossRef]

4. Kempton, W. Electric vehicles: Driving range. Nat. Energy 2016, 1, 16131. [CrossRef]

5. Hardman, S.; Shiu, E.; Steinberger-Wilckens, R. Comparing high-end and low-end early adopters of battery electric vehicles. Transp. Res. Part A Policy Pr. 2016, 88, 40-57. [CrossRef]

6. Von Jouanne, A.; Husain, I.; Wallace, A.; Yokochi, A. Gone with the wind: Innovative hydrogen/fuel cell electric vehicle infrastructure based on wind energy sources. IEEE Ind. Appl. Mag. 2005, 11, 12-19. [CrossRef]

7. Harakawa, T.; Tujimoto, T. Efficient solar power equipment for electric vehicles: Improvement of energy conversion efficiency for charging electric vehicles. In Proceedings of the IEEE International Vehicle Electronics Conference 2001 IVEC 2001 (Cat No 01EX522), Tottori, Japan, 25-28 September 2001; pp. 11-16.

8. Etezadi-Amoli, M.; Choma, K.; Stefani, J. Rapid-Charge Electric-Vehicle Stations. IEEE Trans. Power Deliv. 2010, $25,1883-1887$. [CrossRef]

9. Clement-Nyns, K.; Haesen, E.; Driesen, J. The Impact of Charging Plug-In Hybrid Electric Vehicles on a Residential Distribution Grid. IEEE Trans. Power Syst. 2009, 25, 371-380. [CrossRef]

10. Abella, M.A.; Chenlo, F. Photovoltaic charging station for electrical vehicles. In Proceedings of the 3rd World Conference onPhotovoltaic Energy Conversion, Osaka, Japan, 11-18 May 2003; Volume 3, pp. 2280-2283.

11. Birnie, D.P. Solar-to-vehicle (S2V) systems for powering commuters of the future. J. Power Sources 2009, 186, 539-542. [CrossRef]

12. Fernandez, L.P.; Roman, T.G.S.; Cossent, R.; Domingo, C.M.; Frias, P. Assessment of the Impact of Plug-in Electric Vehicles on Distribution Networks. IEEE Trans. Power Syst. 2011, 26, 206-213. [CrossRef]

13. Huang, Y.; Ye, J.J.; Du, X.; Niu, L.Y. Simulation Study of System Operating Efficiency of EV Charging Stations with Different Power Supply Topologies. Appl. Mech. Mater. 2014, 494, 1500-1508. [CrossRef]

14. Hammerstrom, D.J. AC versus DC distribution systems-did we get it right? In Proceedings of the 2007 IEEE Power Engineering Society General Meeting, PES, Tampa, FL, USA, 24-28 June 2007.

15. Kakigano, H.; Nomura, M.; Ise, T. Loss evaluation of DC distribution for residential houses compared with AC system. In Proceedings of the The 2010 International Power Electronics Conference-ECCE ASIA, IPEC, Sapporo, Japan, 21-24 June 2010.

16. Planas, E.; Andreu, J.; Gárate, J.I.; De Alegría, I.M.; Ibarra, E. AC and DC technology in microgrids: A review. Renew. Sustain. Energy Rev. 2015, 43, 726-749. [CrossRef]

17. Xu, L.; Chen, D. Control and Operation of a DC Microgrid with Variable Generation and Energy Storage. IEEE Trans. Power Deliv. 2011, 26, 2513-2522. [CrossRef]

18. Lago, J.; Heldwein, M.L. Operation and Control-Oriented Modeling of a Power Converter for Current Balancing and Stability Improvement of DC Active Distribution Networks. IEEE Trans. Power Electron. 2011, 26, 877-885. [CrossRef]

19. Tulpule, P.J.; Marano, V.; Yurkovich, S.; Rizzoni, G. Economic and environmental impacts of a PV powered workplace parking garage charging station. Appl. Energy 2013, 108, 323-332. [CrossRef]

20. Shukla, A.; Verma, K.; Kumar, R. Impact of EV fast charging station on distribution system embedded with wind generation. J. Eng. 2019, 2019, 4692-4697. [CrossRef]

21. Khalid, M.R.; Alam, M.S.; Sarwar, A.; Asghar, M.J. A Comprehensive review on electric vehicles charging infrastructures and their impacts on power-quality of the utility grid. eTransportation 2019, 1, 100006. [CrossRef]

22. Hardman, S.; Jenn, A.; Tal, G.; Axsen, J.; Beard, G.; Daina, N.; Figenbaum, E.; Jakobsson, N.; Jochem, P.; Kinnear, N.; et al. A review of consumer preferences of and interactions with electric vehicle charging infrastructure. Transp. Res. Part D Transp. Environ. 2018, 62, 508-523. [CrossRef]

23. Mwasilu, F.; Justo, J.J.; Kim, E.-K.; Do, T.D.; Jung, J.-W. Electric vehicles and smart grid interaction: A review on vehicle to grid and renewable energy sources integration. Renew. Sustain. Energy Rev. 2014, 34, 501-516. [CrossRef]

24. Mohammad, A.; Zamora, R.; Lie, T.T. Integration of Electric Vehicles in the Distribution Network: A Review of PV Based Electric Vehicle Modelling. Energies 2020, 13, 4541. [CrossRef]

25. Khan, S.; Ahmad, A.; Ahmad, F.; Shemami, M.S.; Alam, M.S.; Khateeb, S. A Comprehensive Review on Solar Powered Electric Vehicle Charging System. Smart Sci. 2017, 6, 54-79. [CrossRef]

26. Dallinger, D.; Gerda, S.; Wietschel, M. Integration of intermittent renewable power supply using grid-connected vehicles-A 2030 case study for California and Germany. Appl. Energy 2013, 104, 666-682. [CrossRef]

27. Battke, B.; Schmidt, T.S.; Grosspietsch, D.; Hoffmann, V.H. A review and probabilistic model of lifecycle costs of stationary batteries in multiple applications. Renew. Sustain. Energy Rev. 2013, 25, 240-250. [CrossRef]

28. Alkawsi, G.A.; Baashar, Y. An Empirical Study of the Acceptance of IoT-Based Smart Meter in Malaysia: The Effect of ElectricitySaving Knowledge and Environmental Awareness. IEEE Access 2020, 8, 42794-42804. [CrossRef]

29. Alkawsi, G.A.; Ali, N.; Mustafa, A.S.; Baashar, Y.; Alhussian, H.; Alkahtani, A.; Tiong, S.K.; Ekanayake, J. A hybrid SEM-neural network method for identifying acceptance factors of the smart meters in Malaysia: Challenges perspective. Alex. Eng. J. 2021, 60, 227-240. [CrossRef]

30. Alkawsi, G.A.; Ali, N.A.B. A systematic review of individuals' acceptance of IoT-based technologies. Int. J. Eng. Technol. 2018, 7, 136-142. [CrossRef] 
31. Alkawsi, G.A.; Ali, N.A.B.; Alghushami, A. Toward Understanding Individuals'acceptance of Internet of Things-Based Services: Developing an Instrument to Measure the Acceptance Of Smart Meters. J. Theor. Appl. Inf. Technol. 2018, 96, 13.

32. Alkawsi, G.; Ali, N.A.; Baashar, Y. The Moderating Role of Personal Innovativeness and Users Experience in Accepting the Smart Meter Technology. Appl. Sci. 2021, 11, 3297. [CrossRef]

33. Hussain, A.; Bui, V.-H.; Baek, J.-W.; Kim, H.-M. Stationary Energy Storage System for Fast EV Charging Stations: Simultaneous Sizing of Battery and Converter. Energies 2019, 12, 4516. [CrossRef]

34. Ding, H.; Hu, Z.; Song, Y. Value of the energy storage system in an electric bus fast charging station. Appl. Energy 2015, 157, 630-639. [CrossRef]

35. Ehsan, A.; Yang, Q. Active distribution system reinforcement planning with EV charging stations—Part I: Uncertainty modeling and problem formulation. IEEE Trans. Sustain. Energy 2020, 11, 970-978. [CrossRef]

36. Bao, Y.; Luo, Y.; Zhang, W.; Huang, M.; Wang, L.Y.; Jiang, J. A Bi-Level Optimization Approach to Charging Load Regulation of Electric Vehicle Fast Charging Stations Based on a Battery Energy Storage System. Energies 2018, 11, 229. [CrossRef]

37. Sbordone, D.; Bertini, I.; Di Pietra, B.; Falvo, M.; Genovese, A.; Martirano, L. EV fast charging stations and energy storage technologies: A real implementation in the smart micro grid paradigm. Electr. Power Syst. Res. 2015, 120, 96-108. [CrossRef]

38. Ibrahim, H.; Dimitrova, M.H.; Dutil, Y.; Rousse, D.; Ilinca, A.; Perron, J. Wind-Diesel hybrid system: Energy storage system selection method. In Proceedings of the 12th International Conference on Energy Storage, Leida, Spain, 16-18 May 2012.

39. Tan, N.M.L.; Abe, T.; Akagi, H. Design and Performance of a Bidirectional Isolated DC-DC Converter for a Battery Energy Storage System. IEEE Trans. Power Electron. 2012, 27, 1237-1248. [CrossRef]

40. Ingole, J.N.; Choudhary, M.A.; Kanphade, R.D. Pic Based Solar Charging Controller for Battery. Int. J. Eng. Sci. Technol. 2012, 4, 384-390.

41. Liang, X.; Tanyi, E.; Zou, X. Charging Electric Cars from Solar Energy (Dissertation). 2016. Available online: http://urn.kb.se/ resolve?urn=urn:nbn:se:bth-11919 (accessed on 10 June 2016).

42. Sekhar, K.R.; Gupta, B.K.; Gedam, A.I. The Closed Loop Controller Gain Characterization for Enhanced Current Quality in Solar Inverters Coupled with Weak Grid. In Proceedings of the 2019 8th International Conference on Renewable Energy Research and Applications (ICRERA), Brasov, Romania, 3-6 November 2019; pp. 696-701.

43. Li, X.; Lopes, L.A.; Williamson, S.S. On the suitability of plug-in hybrid electric vehicle (PHEV) charging infrastructures based on wind and solar energy. In Proceedings of the 2009 IEEE Power \& Energy Society General Meeting, Calgary, AB, Canada, 26-30 July 2009; pp. 1-8.

44. Short, W.; Denholm, P. A Preliminary Assessment of Plug-In Hybrid Electric Vehicles on Wind Energy Markets A Preliminary Assessment of Plug-In Hybrid Electric Vehicles on Wind Energy Markets; Technical Report No. NREL/TP-620-39729; National Renewable Energy Lab.(NREL): Golden, CO, USA, 2006.

45. Kaur, S.; Kaur, T.; Khanna, R.; Singh, P. A state of the art of DC microgrids for electric vehicle charging. In Proceedings of the 2017 4th International Conference on Signal Processing, Computing and Control (ISPCC), Solan, India, 21-23 September 2017; Volume 2017, pp. 381-386.

46. Preetham, G.; Shireen, W. Photovoltaic charging station for plug-in hybrid electric vehicles in a smart grid environment. In Proceedings of the 2012 IEEE PES Innovative Smart Grid Technologies, ISGT, Washington, DC, USA, 16-20 January 2012.

47. Goli, P.; Shireen, W. PV integrated smart charging of PHEVs based on DC Link voltage sensing. IEEE Trans. Smart Grid 2014, 5, 1421-1428. [CrossRef]

48. Haque, A.N.M.M.; Saif, A.I.; Nguyen, P.H.; Torbaghan, S.S. Exploration of dispatch model integrating wind generators and electric vehicles. Appl. Energy 2016, 183, 1441-1451. [CrossRef]

49. Noman, F.; Alkahtani, A.A.; Agelidis, V.; Tiong, K.S.; Alkawsi, G.; Ekanayake, J. Wind-Energy-Powered Electric Vehicle Charging Stations: Resource Availability Data Analysis. Appl. Sci. 2020, 10, 5654. [CrossRef]

50. Ghanbarzadeh, T.; Baboli, P.T.; Rostami, M.; Moghaddam, M.P.; Sheikh-El-Eslami, M.K. Wind farm power management by high penetration of PHEV. In Proceedings of the IEEE Power and Energy Society General Meeting, Detroit, MI, USA, 24-28 July 2011.

51. Karabelli, D.; Kiemel, S.; Singh, S.; Koller, J.; Ehrenberger, S.; Miehe, R.; Weeber, M.; Birke, K.P. Tackling xEV Battery Chemistry in View of Raw Material Supply Shortfalls. Front. Energy Res. 2020, 8, 331. [CrossRef]

52. Writer, M.C.S. As Demand for Nickel Grows, So do Environmental Concerns-Report, MININGDOTCOME. Available online: https:/ / www.mining.com/as-demand-for-nickel-grows-so-do-environmental-concerns-report/ (accessed on 27 March 2021).

53. Bailey, J.; Miele, A.; Axsen, J. Is awareness of public charging associated with consumer interest in plug-in electric vehicles? Transp. Res. Part D Transp. Environ. 2015, 36, 1-9. [CrossRef]

54. Nicholas, M.; Tal, G.; Ji, W. Lessons from in-Use Fast Charging Data: Why Are Drivers Staying Close to Home? Research Report. 2017. Available online: https:/ /itspubs.ucdavis.edu/publication_detail.php?id=2699 (accessed on 14 April 2021).

55. Goldin, E.; Erickson, L.; Natarajan, B.; Brase, G.; Pahwa, A. Solar powered charge stations for electric vehicles. Environ. Prog. Sustain. Energy 2013, 33, 1298-1308. [CrossRef]

56. Peterson, S.B.; Michalek, J.J. Cost-effectiveness of plug-in hybrid electric vehicle battery capacity and charging infrastructure investment for reducing US gasoline consumption. Energy Policy 2013, 52, 429-438. [CrossRef]

57. Wood, E.W.; Rames, C.L.; Muratori, M.; Srinivasa Raghavan, S.; Melaina, M.W. National Plug in Electric Vehicle Infrastructure Analysis; Technical Report No. NREL/TP-5400-69031; National Renewable Energy Lab. (NREL): Golden, CO, USA, 2017. 
58. Franke, T.; Krems, J.F. Understanding charging behaviour of electric vehicle users. Transp. Res. Part F Traffic Psychol. Behav. 2013, 21, 75-89. [CrossRef]

59. Lopez-Behar, D.; Tran, M.; Froese, T.; Mayaud, J.R.; Herrera, O.E.; Merida, W. Charging infrastructure for electric vehicles in Multi-Unit Residential Buildings: Mapping feedbacks and policy recommendations. Energy Policy 2019, 126, 444-451. [CrossRef]

60. Lunz, B.; Sauer, D.U. Electric road vehicle battery charging systems and infrastructure. Adv. Battery Technol. Electr. Veh. 2015, 445-467. [CrossRef]

61. Groom, N. Electric Car Maker Tesla Unveils 90-Second Battery Pack Swap. Reuters. 21 June 2013. Available online: https: / / www.reuters.com/article/us-tesla-swap-idUSBRE95K07H20130621 (accessed on 27 March 2021).

62. Zheng, Y.; Dong, Z.Y.; Xu, Y.; Meng, K.; Zhao, J.H.; Qiu, J. Electric Vehicle Battery Charging/Swap Stations in Distribution Systems: Comparison Study and Optimal Planning. IEEE Trans. Power Syst. 2014, 29, 221-2294. [CrossRef]

63. Shareef, H.; Islam, M.; Mohamed, A. A review of the stage-of-the-art charging technologies, placement methodologies, and impacts of electric vehicles. Renew. Sustain. Energy Rev. 2016, 64, 403-420. [CrossRef]

64. Liu, Y.; Hui, F.; Xu, R.; Chen, T.; Xu, X.; Li, J. Investigation on the Construction Mode of the Charging Station and Battery-Exchange Station. In Proceedings of the 2011 Asia-Pacific Power and Energy Engineering Conference, Wuhan, China, 25-28 March 2011.

65. Liu, C.; Wang, J.; Botterud, A.; Zhou, Y.; Vyas, A. Assessment of Impacts of PHEV Charging Patterns on Wind-Thermal Scheduling by Stochastic Unit Commitment. IEEE Trans. Smart Grid 2012, 3, 675-683. [CrossRef]

66. Ortega-Vazquez, M.A.; Bouffard, F.; Silva, V. Electric Vehicle Aggregator/System Operator Coordination for Charging Scheduling and Services Procurement. IEEE Trans. Power Syst. 2013, 28, 1806-1815. [CrossRef]

67. Haddadian, G.; Khalili, N.; Khodayar, M.; Shahidehpour, M. Optimal coordination of variable renewable resources and electric vehicles as distributed storage for energy sustainability. Sustain. Energy Grids Networks 2016, 6, 14-24. [CrossRef]

68. Jin, C.; Sheng, X.; Ghosh, P. Optimized Electric Vehicle Charging with Intermittent Renewable Energy Sources. IEEE J. Sel. Top. Signal Process. 2014, 8, 1063-1072. [CrossRef]

69. Liu, H.; Zeng, P.; Guo, J.; Wu, H.; Ge, S. An optimization strategy of controlled electric vehicle charging considering demand side response and regional wind and photovoltaic. J. Mod. Power Syst. Clean Energy 2015, 3, 232-239. [CrossRef]

70. Quddus, M.A.; Kabli, M.; Marufuzzaman, M. Modeling electric vehicle charging station expansion with an integration of renewable energy and Vehicle-to-Grid sources. Transp. Res. Part E Logist. Transp. Rev. 2019, 128, 251-279. [CrossRef]

71. Pan, F.; Bent, R.; Berscheid, A.; Izraelevitz, D. Locating PHEV Exchange Stations in V2G. In Proceedings of the 2010 First IEEE International Conference on Smart Grid Communications, Gaithersburg, MD, USA, 4-6 October 2010.

72. Manfren, M.; Nastasi, B.; Groppi, D.; Garcia, D.A. Open data and energy analytics-An analysis of essential information for energy system planning, design and operation. Energy 2020, 213, 118803. [CrossRef]

73. Zhang, H.; Moura, S.J.; Hu, Z.; Qi, W.; Song, Y. Joint PEV Charging Network and Distributed PV Generation Planning Based on Accelerated Generalized Benders Decomposition. IEEE Trans. Transp. Electrif. 2018, 4, 789-803. [CrossRef]

74. Bascetta, L.; Gruosso, G.; Gajani, G.S. A Data Driven Approach to Model Electrical Vehicle Charging Behaviour for Grid Integration Analysis. In Proceedings of the 2018 IEEE Vehicle Power and Propulsion Conference (VPPC), Chicago, IL, USA, 27-30 August 2019.

75. Yang, J.; Dong, J.; Hu, L. A data-driven optimization-based approach for siting and sizing of electric taxi charging stations. Transp. Res. Part C Emerg. Technol. 2017, 77, 462-477. [CrossRef]

76. Zhu, N.; Fu, C.; Ma, S. Data-driven distributionally robust optimization approach for reliable travel-time-information-gainoriented traffic sensor location model. Transp. Res. Part B Methodol. 2018, 113, 91-120. [CrossRef]

77. Xie, R.; Wei, W.; Khodayar, M.E.; Wang, J.; Mei, S. Planning Fully Renewable Powered Charging Stations on Highways: A Data-Driven Robust Optimization Approach. IEEE Trans. Transp. Electrif. 2018, 4, 817-830. [CrossRef]

78. Ekren, O.; Canbaz, C.H.; Güvel, Ç.B. Sizing of a solar-wind hybrid electric vehicle charging station by using HOMER software. J. Clean. Prod. 2021, 279, 123615. [CrossRef]

79. Zhang, Y.; Liu, N.; Zhang, J.; Yingda, Z.; Nian, L.; Jianhua, Z. Optimum sizing of non-grid-connected wind power system incorporating battery-exchange stations. In Proceedings of the 7th International Power Electronics and Motion Control Conferenceno, Harbin, China, 2-5 June 2012; pp. 2123-2128.

80. Moradi, M.H.; Abedini, M.; Tousi, S.R.; Hosseinian, S.M. Electrical Power and Energy Systems Optimal siting and sizing of renewable energy sources and charging stations simultaneously based on Differential Evolution algorithm. Int. J. Electr. Power Energy Syst. 2015, 73, 1015-1024. [CrossRef]

81. Mozafar, M.R.; Moradi, M.H.; Amini, M.H. A simultaneous approach for optimal allocation of renewable energy sources and electric vehicle charging stations in smart grids based on improved GA-PSO algorithm. Sustain. Cities Soc. 2017, 32, 627-637. [CrossRef]

82. Hafez, O.; Bhattacharya, K. Optimal design of electric vehicle charging stations considering various energy resources. Renew. Energy 2017, 107, 576-589. [CrossRef]

83. Grande, L.S.A.; Yahyaoui, I.; Gómez, S.A. Energetic, economic and environmental viability of o ff-grid PV-BESS for charging electric vehicles: Case study of Spain. Sustain. Cities Soc. 2018, 37, 519-529. [CrossRef]

84. Hussain, A.; Bui, V.-H.; Kim, H.-M. Optimal Sizing of Battery Energy Storage System in a Fast EV Charging Station Considering Power Outages. IEEE Trans. Transp. Electrif. 2020, 6, 453-463. [CrossRef] 
85. Aghapour, R.; Sepasian, M.S.; Arasteh, H.; Vahidinasab, V.; Catalão, J.P. Probabilistic planning of electric vehicles charging stations in an integrated electricity-transport system. Electr. Power Syst. Res. 2020, 189, 106698. [CrossRef]

86. Yilmaz, M.; Krein, P.T. Review of the Impact of Vehicle-to-Grid Technologies on Distribution Systems and Utility Interfaces. IEEE Trans. Power Electron. 2013, 28, 5673-5689. [CrossRef]

87. Bai, S.; Yu, D.; Lukic, S. Optimum design of an EV/PHEV charging station with DC bus and storage system. In Proceedings of the 2010 IEEE Energy Conversion Congress and Exposition, Atlanta, GA, USA, 12-16 September 2010; pp. 1178-1184.

88. Noussan, M.; Roberto, R.; Nastasi, B. Performance Indicators of Electricity Generation at Country Level-The Case of Italy. Energies 2018, 11, 650. [CrossRef]

89. Abronzini, U.; Attaianese, C.; D'Arpino, M.; Di Monaco, M.; Genovese, A.; Pede, G.; Tomasso, G. Optimal energy control for smart charging infrastructures with ESS and REG. In Proceedings of the 2016 International Conference on Electrical Systems For Aircraft, Railway, Ship Propulsion and Road Vehicles \& International Transportation Electrification Conference (ESARS-ITEC), Toulouse, France, 2-4 November 2016; pp. 1-6.

90. Green, R.C.; Wang, L.; Alam, M. The impact of plug-in hybrid electric vehicles on distribution networks: A review and outlook. Renew. Sustain. Energy Rev. 2010, 15, 544-553. [CrossRef]

91. Amini, M.H.; Kargarian, A.; Karabasoglu, O. ARIMA-based decoupled time series forecasting of electric vehicle charging demand for stochastic power system operation. Electr. Power Syst. Res. 2016, 140, 378-390. [CrossRef]

92. Kelly, L.; Rowe, A.; Wild, P. Analyzing the impacts of plug-in electric vehicles on distribution networks in British Columbia. In Proceedings of the 2009 IEEE Electrical Power \& Energy Conference (EPEC), Montreal, QC, Canada, 22-23 October 2009.

93. Song, J.; Suo, L.; Han, M.; Wang, Y. A Coordinated Charging/Discharging Strategy for Electric Vehicles Based on Price Guidance Mechanism. IOP Conf. Ser. Mater. Sci. Eng. 2019, 677, 52103. [CrossRef]

94. Liu, F.; Yang, X.; Shi, S.; Zhang, M.; Deng, H.; Guo, P. Economic operation of microgrid containing charging-swapping-storage integrated station under uncertain factors of wind farm and photovoltaic generation. Power Syst. Technol. 2015, 39, 669-676.

95. Xu, Z.; Su, W.; Hu, Z.; Song, Y.; Zhang, H. A Hierarchical Framework for Coordinated Charging of Plug-In Electric Vehicles in China. IEEE Trans. Smart Grid 2016, 7, 428-438. [CrossRef]

96. Wi, Y.-M.; Lee, J.-U.; Joo, S.-K. Electric vehicle charging method for smart homes/buildings with a photovoltaic system. IEEE Trans. Consum. Electron. 2013, 59, 323-328. [CrossRef]

97. Shimomachi, K.; Hara, R.; Kita, H.; Noritake, M.; Hoshi, H.; Hirose, K. Development of energy management system for DC microgrid for office building:-Day Ahead operation scheduling considering weather scenarios. In Proceedings of the 2014 Power Systems Computation Conference, Wroclaw, Poland, 18-22 August 2014; pp. 1-6.

98. Del Razo, V.; Goebel, C.; Jacobsen, H.A. Vehicle-Originating-Signals for Real-Time Charging Control of Electric Vehicle Fleets. IEEE Trans. Transp. Electrif. 2015, 1, 150-167. [CrossRef]

99. Liao, Y.-T.; Lu, C.-N. Dispatch of EV Charging Station Energy Resources for Sustainable Mobility. IEEE Trans. Transp. Electrif. 2015, 1, 86-93. [CrossRef]

100. Carpinelli, G.; Mottola, F.; Proto, D. Optimal scheduling of a microgrid with demand response resources. IET Gener. Transm. Distrib. 2014, 8, 1891-1899. [CrossRef]

101. Kumar, K.N.; Sivaneasan, B.; So, P.L. Impact of Priority Criteria on Electric Vehicle Charge Scheduling. IEEE Trans. Transp. Electrif. 2015, 1, 200-210. [CrossRef]

102. Bokopane, L.; Kusakana, K.; Vermaak, H. Optimal energy management of an isolated electric Tuk-Tuk charging station powered by hybrid renewable systems. In Proceedings of the 2015 International Conference on the Domestic Use of Energy (DUE), Cape Town, South Africa, 31 March-1 April 2015.

103. Wang, H.; Balasubramani, A.; Ye, Z. Optimal Planning of Renewable Generations for Electric Vehicle Charging Station. In Proceedings of the 2018 International Conference on Computing, Networking and Communications (ICNC), Maui, HI, USA, 5-8 March 2018; pp. 63-67.

104. Fathabadi, H. Novel wind powered electric vehicle charging station with vehicle-to-grid (V2G) connection capability. Energy Convers. Manag. 2017, 136, 229-239. [CrossRef]

105. Badawy, M.O.; Sozer, Y. Power Flow Management of a Grid Tied PV-Battery System for Electric Vehicles Charging. IEEE Trans. Ind. Appl. 2016, 53, 1347-1357. [CrossRef]

106. Ashique, R.H.; Salam, Z.; Aziz, M.J.B.A.; Bhatti, A.R. Integrated photovoltaic-grid dc fast charging system for electric vehicle: A review of the architecture and control. Renew. Sustain. Energy Rev. 2017, 69, 1243-1257. [CrossRef]

107. Ross, M.; Hidalgo, R.; Abbey, C.; Joós, G. Energy storage system scheduling for an isolated microgrid. IET Renew. Power Gener. 2011, 5, 117-123. [CrossRef]

108. Liu, N.; Chen, Q.; Liu, J.; Lu, X.; Li, P.; Lei, J.; Zhang, J. A Heuristic Operation Strategy for Commercial Building Microgrids Containing EVs and PV System. IEEE Trans. Ind. Electron. 2015, 62, 2560-2570. [CrossRef]

109. Byeon, G.; Yoon, T.; Oh, S.; Jang, G. Energy Management Strategy of the DC Distribution System in Buildings Using the EV Service Model. IEEE Trans. Power Electron. 2012, 28, 1544-1554. [CrossRef]

110. Pflaum, P.; Alamir, M.; Lamoudi, M.Y. Probabilistic Energy Management Strategy for EV Charging Stations Using Randomized Algorithms. IEEE Trans. Control. Syst. Technol. 2017, 26, 1099-1106. [CrossRef]

111. Chen, C.; Duan, S. Optimal Integration of Plug-In Hybrid Electric Vehicles in Microgrids. IEEE Trans. Ind. Informatics 2014, 10, 1917-1926. [CrossRef] 
112. Bracco, S.; Delfino, F.; Pampararo, F.; Robba, M.; Rossi, M. A dynamic optimization-based architecture for polygeneration microgrids with tri-generation, renewables, storage systems and electrical vehicles. Energy Convers. Manag. 2015, 96, 511-520. [CrossRef]

113. Honarmand, M.; Zakariazadeh, A.; Jadid, S. Integrated scheduling of renewable generation and electric vehicles parking lot in a smart microgrid. Energy Convers. Manag. 2014, 86, 745-755. [CrossRef]

114. Wu, D.; Zeng, H.; Lu, C.; Boulet, B. Two-Stage Energy Management for Office Buildings With Workplace EV Charging and Renewable Energy. IEEE Trans. Transp. Electrification 2017, 3, 225-237. [CrossRef]

115. Nextera Energy. Annual Report Fiscal Year 2017; Nextera Energy: Juno Beach, FL, USA, 2017.

116. Mudd, S. Interview: Xcel Energy Windsource Program Celebrates Several Milestones. Haskard 2013. Available online: https: / / www.cleanenergyresourceteams.org/interview-xcel-energy-windsource-program-celebrates-several-milestones (accessed on 27 March 2021).

117. Hutchinson, N.; Bird, L. A Review of Utility Program Designs E Implementation Strategies; World Resources Institute: Washington, DC, USA, 2019.

118. Trabish, H. Co-op Offers Renewables Only EV Charging, Highlighting New Opportunity for Utilities. Util. Dive 2017. Available online: https: / www.utilitydive.com/news/co-op-offers-renewables-only-ev-charging-highlighting-new-opportunity-for/ 400779/ (accessed on 21 January 2021).

119. Noble, M. Partnering with Great River Energy on Our Path to Electrify the Econom. Renew. Electr. 2016. Available online: https: / / fresh-energy.org/partnering-with-great-river-energy-on-our-path-to-electrify-the-economy (accessed on 21 January 2021).

120. Liang, X. Emerging Power Quality Challenges Due to Integration of Renewable Energy Sources. IEEE Trans. Ind. Appl. 2017, 53, 855-866. [CrossRef]

121. Nijhuis, M.; Gibescu, M.; Cobben, J.F.G. Application of resilience enhancing smart grid technologies to obtain differentiated reliability. In Proceedings of the 2016 IEEE 16th International Conference on Environment and Electrical Engineering (EEEIC), Florence, Italy, 7-10 June 2016; pp. 1-6.

122. Min, C.-G.; Kim, M.-K. Net Load Carrying Capability of Generating Units in Power Systems. Energies 2017, 10, 1221. [CrossRef]

123. Otsuki, T. Costs and benefits of large-scale deployment of wind turbines and solar PV in Mongolia for international power exports. Renew. Energy 2017, 108, 321-335. [CrossRef] 